\title{
Endemic Philippine teak (Tectona philippinensis Benth. \& Hook. f.) and associated flora in the coastal landscapes of Verde Island Passage, Luzon Island, Philippines
}

\author{
Anacleto M. Caringal ${ }^{1,2}$, Inocencio E. Buot, $\mathrm{Jr}^{2,3,4, *}$ and \\ Elaine Loreen C. Villanueva ${ }^{3}$ \\ ${ }^{1}$ Batangas State University-Lobo, Lobo, Batangas, Philippines \\ ${ }^{2}$ School of Environmental Science and Management, University of the Philippines Los Baños, Laguna, Philippines \\ ${ }^{3}$ Institute of Biological Sciences, College of Arts and Sciences, University of the Philippines Los Baños, Laguna, Philippines \\ ${ }^{4}$ Faculty of Management and Development Studies, University of the Philippines Open University, Los Baños, Laguna, Philippines
}

\begin{abstract}
The Philippine teak forest (PTF) is a formation with the Endangered Tectona philippinensis Benth. \& Hook. f., Lamiaceae - an endemic tree flora in the Batangas Province along the Verde Island Passage, Luzon Island, Philippines. In this study, we determine the general floristic composition of PTF. Vegetation analysis across coastal to inland continuum generated the data for general floristic richness, growth structure and diversity indices. A total of 128 species under 111 genera in 48 families was recorded with overall plant diversity of very low to moderate (Shannon-Wiener: 0.8675-2.681). Plant life based on morpho-species was composed of dominant trees (68 species), shrubs (5) and subshrubs (9), bush palm (1) and palm-like tree (1), lianas (7), epiphytic tree (1), semi-woody climbers (3), epiphytic and geophytic orchids (4), epiphytic and terrestrial ferns (5), annuals to erect succulent perennial herbs (9), herbaceous climbers and creepers (6), geophytic herbs and climber (1), low and tall grasses, including bamboo (5) and sedges (2). Such structural diversity is comprised of some of the unique botanical ensembles associated with endemic $T$. philippinensis in the coastal landscape.
\end{abstract}

Keywords: Coastal landscape, epiphytes, Tectona philippinensis, teak forest.

THE tropical forests of Southeast Asia differ in floristic composition, diversity and structural ensembles due to biogeography and environmental heterogeneity ${ }^{1-9}$. Across the Philippines, diverse natural forests exist with distinct species composition and structure ${ }^{10-12}$. These ecotypes or formations ranging from sea level to over $2954 \mathrm{~m}$ altitudes (i.e. mangroves, beaches, freshwater peat swamps, forests over ultramafic soils and limestone karst, semi-

*For correspondence. (e-mail: iebuot@up.edu.ph) deciduous forests, pines, lower and upper montane forests and sub-alpine) based on the dominant floristic elements have been the focus of ecological classification since 1900s (refs 13-16). The Philippine teak forest (PTF), however, has not yet been included in these national classifications.

The forest with endemic Tectona philippinensis Benth. \& Hook. f., (APG: Lamiaceae) has long been considered as one of the most important areas of floristic richness ${ }^{10,17,18}$. Until the present study, however, PTF remains to be classified among the major forest ecotypes in the Philippines. Ecological studies for PTF have specially focused on phenological synchrony ${ }^{19,20}$, xerophytic adaptation $^{21}$, genetic diversity ${ }^{22}$, and a pioneering conservation assessment for the International Union for the Conservation of Nature (IUCN) ${ }^{23}$. However, there is less information on landscape-level details about the floristic elements and structure across the Verde Island Passage Marine Corridor (VIPMC), an area of conservation importance within the Southern Luzon Biogeographic Region of the Phillippines ${ }^{24,25}$.

T. philippinensis was first described by British botanists George Bentham and Joseph D. Hooker (1876) based on the specimens deposited at London's Kew Herbarium. The species was collected by the English naturalist Hugh Cuming (1432) from the shores of Batangas, Luzon, Phillippines ${ }^{17}$. Since then, the Philippine teak is of special interest to phytogeographers in the Malesian region.

The Batangas Province has one of the fastest rates of land-use conversion in the Philippines ${ }^{26}$. Massive development of road networks and lateral expansion of urban settlements to outlying rural districts have been ongoing in Batangas during the last 30 years $^{26}$. Madulid et al. ${ }^{23}$ reported for the Species Survival Commission of the IUCN that these developments have threatened the natural population of $T$. philippinensis in the Province. Hence, 


\section{RESEARCH ARTICLES}

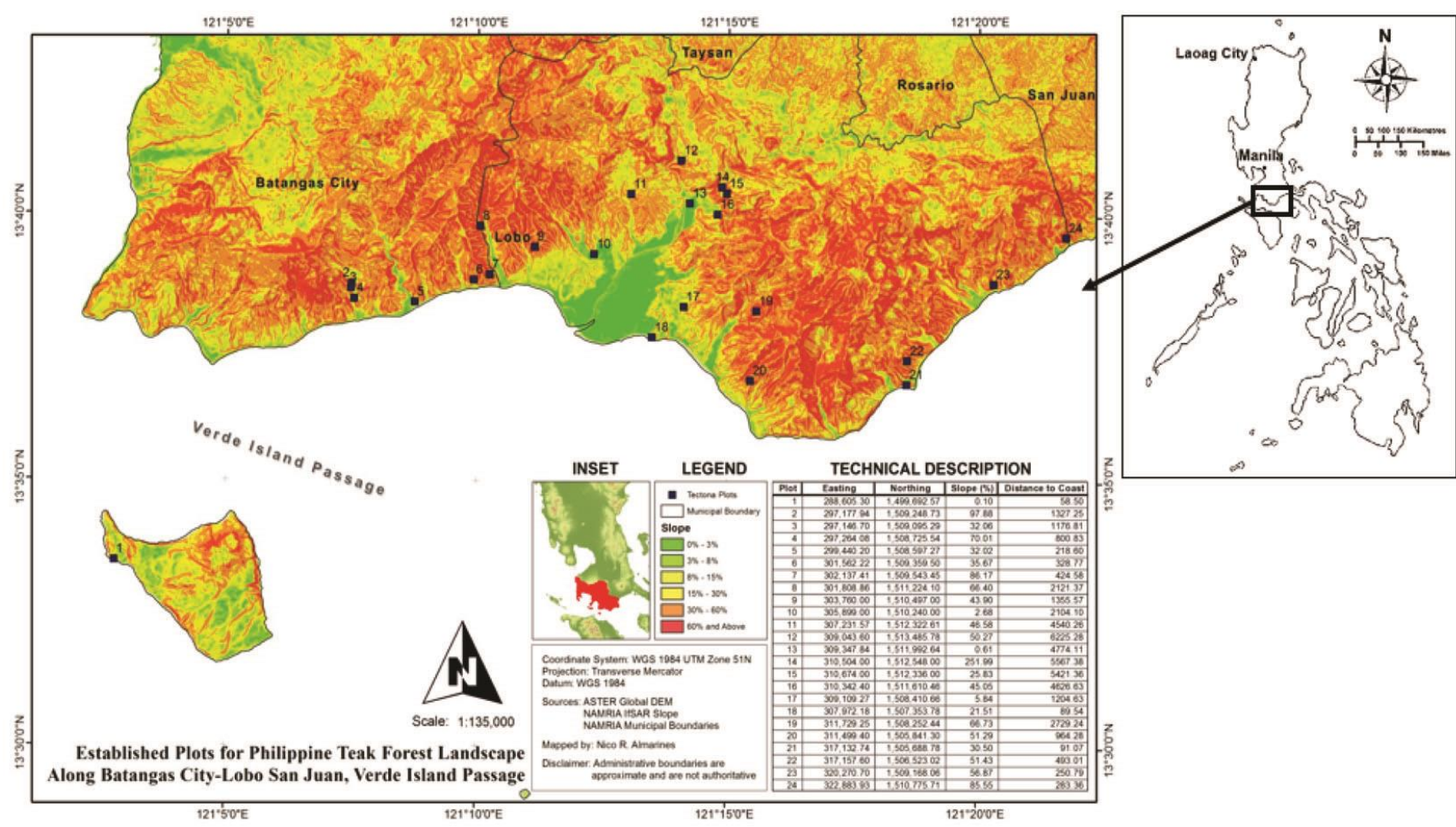

Figure 1. Study area showing the coastal landscapes of island-mainland municipalities of Batangas City, Lobo, and San Juan, Batangas province, Philippines, where Philippine teak forest (PTF) was sampled. Sampling plots are marked as black squares.

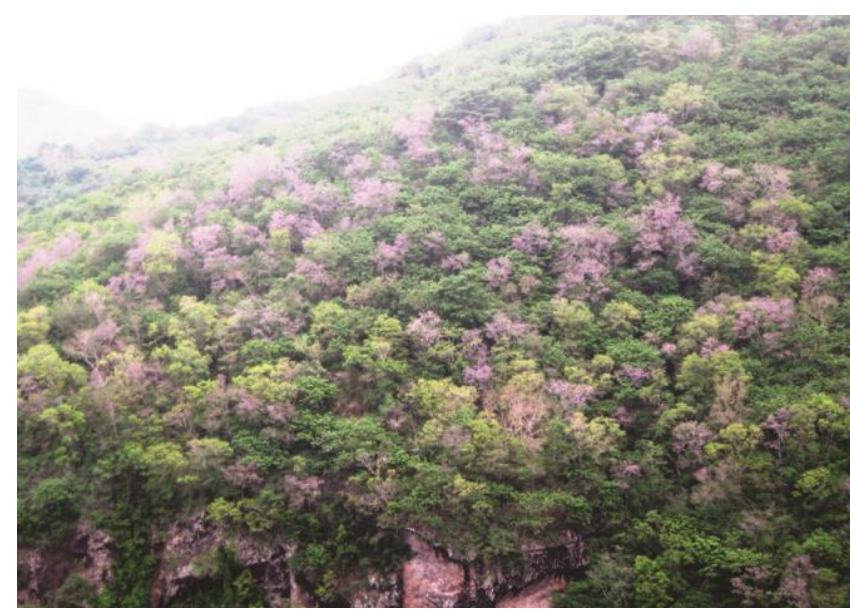

Figure 2. PTF in the satoyama landscape at Lobo, Batangas.

this study reveals the species composition and structure of PTF which can be lost or degraded in the course of these anthropogenic expansions. The results can be used as an input in designing and implementing native forest restoration projects, particularly in the locally important biodiversity conservation corridor.

As there are fewer accurate reports on the floristic composition and structure about PTF, this study aims to describe the species composition and vegetation structure of the PTF.

\section{Materials and methods}

\section{Study area}

The study was conducted along Isla Verde-Batangas City-Lobo-San Juan coastal landscapes in Batangas Province $\left(8-321 \mathrm{~m}\right.$ asl, $13^{\circ} 30^{\prime}-13^{\circ} 40^{\prime} \mathrm{N}$ and $121^{\circ} 05^{\prime}-$ $121^{\circ} 15^{\prime} \mathrm{E}$ ), southwestern Luzon, Philippines (Figures 1 and 2). The 24 study plots (marked as black squares in the map) from Isla Verde to the mainland $(56.48 \mathrm{~km}$ connectivity) have gentle to undulating, rolling to moderately steep slopes (0.10-51.99\%), located for some distance $(58.5-6225.28 \mathrm{~m})$ along the coastal cliff towards inland ridges and narrow valley facing the sea of Verde Island Passage. The landscape consists of volcanic agglomerates from various ages such as Talahib Andesite (Upper Oligocene-Miocene), Lobo agglomerate (PleiocenePleistocene) and San Juan Quartz Diorite (Lower Miocene) where the underlying geography is shallow, soft and porous reef limestone (Pleistocene), including bushes of corals, shells, algae structure and recent alluvium formation ${ }^{27-29}$.

The mean annual precipitation for 1980-2016 was $151.89 \mathrm{~mm}$ in Batangas Province. Highest precipitation (113-331 mm) was observed during the southwest monsoon season, viz. May to July, which decreased (292-101 mm) from August to December. Low rainfall (27-32 mm) was experienced during summer, viz. January to April. The 
annual mean temperature for the same period at the weather station was $27.36^{\circ} \mathrm{C}$, ranging from $26^{\circ} \mathrm{C}$ to $29^{\circ} \mathrm{C}$.

\section{Methods of floristic inventory and diversity analysis}

Vegetation data were collected between October 2016 and February 2017 from $2420 \mathrm{~m} \times 20 \mathrm{~m}$ (=0.96 ha) plots, which were randomly established along the $56 \mathrm{~km}$ islandmainland agro-ecosystem continuum. Altitudes and coordinates of all study plots were taken using a Garmin 76Csx global positioning system receiver. In each plot, $100 \%$ tallying (abundance count) of woody and non-woody species was done. The diameter at breast height of trees (at least $\geq 10 \mathrm{~cm}$ ) was measured with a diameter tape at $1.3 \mathrm{~m}$ from the ground, while heights were measured using a tree height meter from the base to the topmost part of the crown. The tree heights were estimated visually ${ }^{30}$. Crown dimensions were measured by a meter tape ${ }^{31}$. Photographs of plant life were taken. Specimens were collected with the aid of climbers and prepared into herbarium vouchers lodged at the Batangas State University Herbarium in Lobo Batangas, Philippines. Duplicate vouchers were deposited at the Plant Biology Division Herbarium (PBDH), Plant Systematics Laboratory, Institute of Biological Sciences, College of Arts and Sciences, University of the Philippines at Los Baños.

At least $85-90 \%$ of floristic morpho-species (trees, shrubs, vines, herbs, ferns and epiphytes) were enumerated. Species nomenclature and growth forms classification were done according to the literature ${ }^{32-36}$. The families of ferns followed the classification by Smith et al. ${ }^{37}$ and that of Pteridophytes Phylogeny Group ${ }^{38}$, while angiosperms and gymnosperms followed the subsequent classification updates (1997-2016) of the Angiosperm Phylogeny Group (APG) ${ }^{39}$.

The species richness (SR) and total abundance or number of individuals $(N)$ were derived from species enumeration and density tallying count, while the ShannonWeiner diversity index $\left(H^{\prime}\right)$ and other diversity indices were generated using the Microsoft Excel (2007) table data in the BioDiversityPro software ${ }^{40}$ and Paleontological Statistics (PAST, version 2.10) ${ }^{41}$.

\section{Results}

\section{Floristic composition of the Philippine teak forest}

Supplementary Table 1 shows all the observed species $\left(S_{\text {obs }}\right)$ other than trees as suggested by Langenberger ${ }^{42}$, with notes about growth habit, habitats, abundance records, occurrences and as well as geographic affinity. Altogether, four subspecies and four varieties belonging to 128 species under 113 genera in 46 families were recorded from the 24 plots. Following the species abundance classification of Colwell ${ }^{43}, 80(63 \%)$ of the total 128 observed species in this study were considered abundant each with more than ten individuals, while 29 species $(23 \%)$ as rare - each with at least three or fewer than ten individuals. Six species $(4 \%)$ were rare doubletons - with exactly two individuals, while 13 species $(10 \%)$ were rare singletons - with exactly a single individual.

The most abundant native trees were Tectona philippinensis with 6340 individuals, followed by Hibiscus tiliaceous L. subsp. tiliaceous (611), Terminalia polyantha (560), Memecylon edule (472), Murraya paniculata (147) and Vitex parviflora (129). Leucaena leucocephala (1992) and Tamarindus indica (164) were the most abundant cultivated trees, while shrubs and ruderal undershrubs such as Lantana camara (499), Acalypha amentacea (454), Sida rhombifolia ssp. rhombifolia (1182), Ageratum conzoides (1721), Hyptis soaveolens (652), Crossandra infundibuliformis (506) and Chromolaena odorata (435) were also common.

Epiphytic and terrestrial pteridophytes were observed owing to high abundance of Adiantum caudatum (3186), Drynaria quercifolia (520), Sellaginella tamariscina (205) and Adiantum philippense (148). The rare doubletons included Cordia dichotoma, Diospyros ferrea, Albizia procera, Alseodaphne malabonga, Streblus ilicifolius and Syzygium mindorensis. The rarest unique singletons were trees such as Mallotus philippensis, Caesalpinia bonduc, Prosopis juliflora, Bombax ceiba, Heretiera sylvatica, Ficus spp., Guettarda speciosa, Morinda citrifolia, Trigonachras cuspidata and an orchid - Trichoglottis latisepala (Supplementary Table 1: N/F).

There were 108 species of angiosperm dicots and 14 species of monocots, one gymnosperm (Cycas edentata de Laubenfels) and five species of pteridophytes. The species rich plant groups were Fabaceae (18 species), Malvaceae (15), Lamiaceae (7), Apocynaceae, Euphorbiaceae and Moraceae (with 6 species each); as well as Asteraceae, Malvaceae, Poaceae and Rubiaceae (with 5 species each). Orchids and sapindaceous flora with four species each were also unique elements of PTF (Supplementary Table 1).

Many growth forms were disturbance-indicators (38 species in Table 1), such as herbs (Achyranthes, Ageratum, Euphorbia, Phyllanthus, etc.), climbers and vines (Chromolaena, Ipomea, Caesalpinia, Centrosema), grasses (Dactyloctenium, Leersia, Saccharum), shrubs and subshrubs (Acacia, Capsicum, Crossandra, Flemengia, Lantana, Stachytarpeta) and some trees (Gliricidia, Gmelina, Leucaena, Psidium). There were also common pioneer trees of Philippine secondary growth forest (Supplementary Table 1) represented by five genera (Bauhinia, Macaranga, Mallotus, Melanolepis and Tre$\mathrm{ma}$ ), whereas the 'foundation species' of tropical beach forest such as Guettarda speciosa, Prosopis juliflora, Thespesia populnea, Terminalia catappa and Xylocarpus 


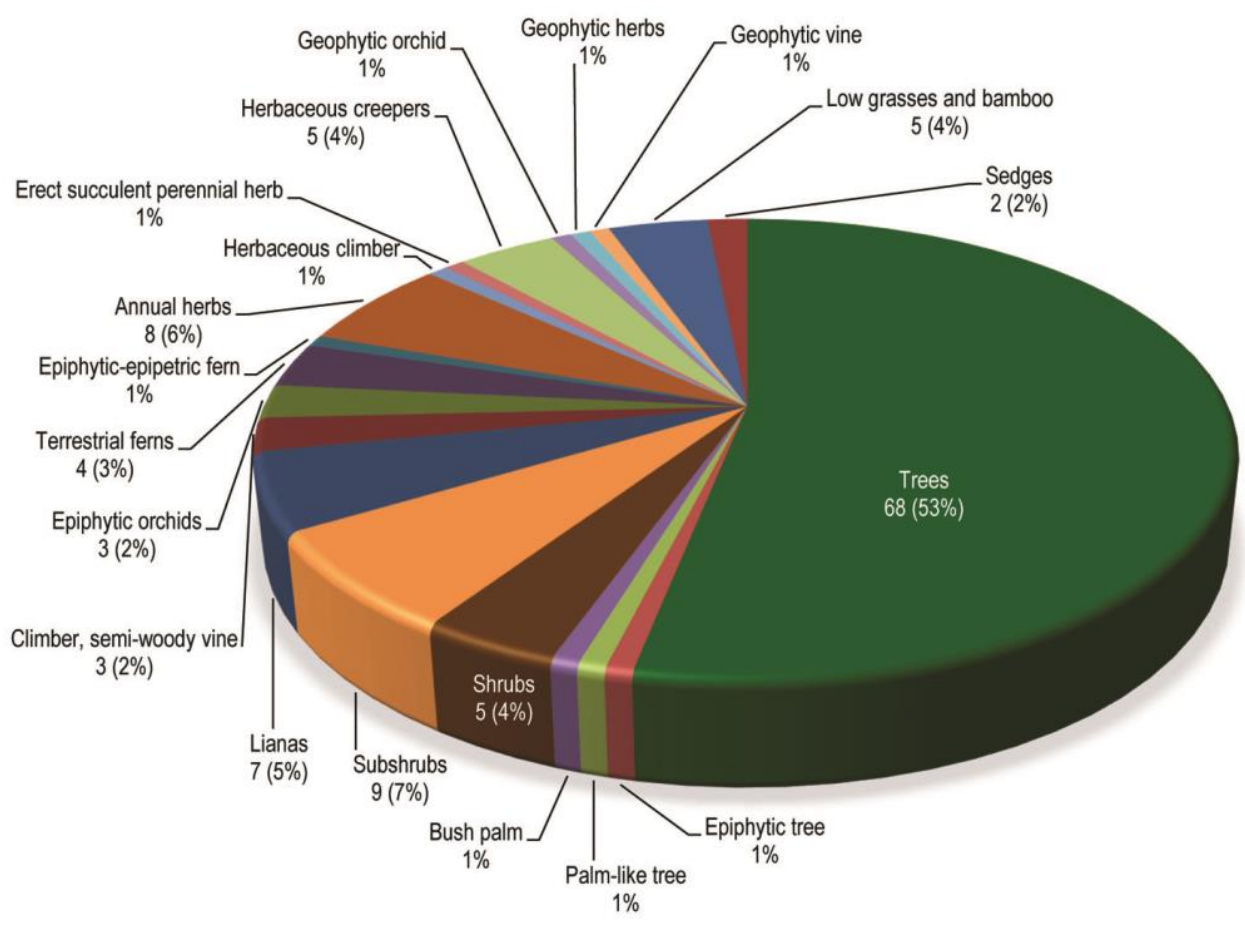

Figure 3. Diversity of plant life structure in PTF.

rumphii were found to be associated with endemic $T$. philippinensis.

In terms of phytogeographic affinity (Supplementary Table 1), many of the floristic elements were of Malesian, Asiatic, Australia-Asian to Pantropic distribution. Interestingly, there were seven tree flora reported as Luzon's endemic encountered in the study sites: Arenga tremula (Arecaceae), Callicarpa erioclana (Lamiaceae), Garuga floribunda (Burseraceae), Scolopia luzonensis (Flacourtiaceae), Tectona philippinensis (Lamiaceae), Terminalia polyantha (Combretaceae) and Syzygium mindorense (Myrtaceae). Many of the enumerated species are indigenous or can be found throughout the Philippines and in the Malesian phytogeographic region.

\section{Vegetation structure}

The different growth habits or life-form structures which are the valid primary elements of vegetation type or plant association were observed in different morpho-species in the PTF (Figure 3) ${ }^{44-46}$. There were trees (68 species), shrubs (5) and subshrubs (9), bush palm (1) and palm-like tree (1), lianas (7), epiphytic tree (1), semi-woody climbers (3), epiphytic and geophytic orchids (4), epiphytic and terrestrial ferns (5), annuals to erect succulent perennial herbs (9), herbaceous climbers and creepers (6), geophytic herbs and climber (1), low and tall grasses, including bamboo (5) and sedges (2). Physiognomically, such structural diversity comprises some of the unique botanical ensembles in the PTF landscape.

\section{Diversity analysis of the flora}

Table 1 presents the comparative measures of diversity for the general floristic composition of PTF. The proportion of abundance among species resulted in 'very low to moderate level of diversity', as reflected in abundancedependent Shannon-Wiener index $\left(H^{\prime}\right)$, with values ranging between 0.84 and 2.69 across plots (Figure 4). This can be attributed to the disproportion of abundance among species, but if taken collectively, the PTF consists of highly abundant plant population $(\mathrm{N})$ resulting in high abundance to species richness ratio (N/SR; Table 1).

SR as a direct measure of diversity varied across the 24 sites with 15-42 species and was within Chao-1 estimate of 15-50 species. SR also complements the results of Hill's diversity numbers. Chao- 1 and Chao-2 SR estimators revealed that there was a minimum of 141 species and maximum of 172 species (Table 2). This is an indication of the possible range of SR in PTF as there are species that might not have been recorded during sampling. Even so, both estimates revealed that the total SR (128 species) in the present study accounts for 74.56-90.78\% of the potential range of SR. Moreover, the species accumulation curve for the 24 sites shows gradual elevation and has not attained its asymptote (Figure 5), suggesting that if sampling efforts continue, there may be additional species.

Considering both the maximum and mean values, Fischer's $\alpha$ and Margalef index gave the highest diversity values for PTF, as these two indices were weighted to SR 
RESEARCH ARTICLES

Table 1. Diversity value indices for the general floristic composition of the Philippine teak forest (PTF) (pooled from 24 quadrats)

\begin{tabular}{|c|c|c|}
\hline Indices/measures of diversity & $\begin{array}{l}\text { Minimum-maximum } \\
\text { values ( } 24 \text { sites; } \\
\text { mean value) }\end{array}$ & Relevance to the structure and dynamics of PTF \\
\hline Shannon-Wiener $\left(H^{\prime}\right)$ & $0.87-2.69(1.97)$ & $\begin{array}{l}\text { PTF has very low to moderate level of diversity resulting from the dominance of most } \\
\text { abundant species. } H^{\prime} \text { value usually lies between } 1.5-3.5 \text { and rarely exceeds } 4.0^{65} \text {. }\end{array}$ \\
\hline Species richness (SR) & $15-42(26)$ & Species-rich forest; heterogeneous at the habitat level $\mathrm{l}^{47,66-70}$. \\
\hline Hill's diversity numbers & $13-42(25)$ & Reflect similar information with SR about effective number of (observed) species ${ }^{71,72}$. \\
\hline Chao-1 (SR estimator) & $15-50(30)$ & $\begin{array}{l}\text { More unseen species were detected from the abundance of singleton }(1 N) \text { species, but } \\
\text { SR was within Chao-1 values, where at least } 90.78 \% \text { was the degree of species } \\
\text { collection effort. }\end{array}$ \\
\hline Species abundance $(N)$ & $242-2,707(1060)$ & $\begin{array}{l}\text { PTF consists of abundant plant population (abundant }>10 \mathrm{~N} \text {, rare } 3-9 \mathrm{~N} \text {, doubleton } 2 \mathrm{~N} \\
\text { and singleton } 1 \mathrm{~N} \text { ) }{ }^{43} \text {. }\end{array}$ \\
\hline $\mathrm{N} / \mathrm{SR}$ ratio & $11.2-110(43.38)$ & There was abundant number of individuals among species in the PTF. \\
\hline Fischer's $\alpha$ & $2.4-9.72(5.18)$ & $\begin{array}{l}\text { PTF has low to very high diversity attributed to SR regardless of abundance distribution } \\
\text { among species }{ }^{47-49} \text {. }\end{array}$ \\
\hline Margalef's richness index & $1.96-6.23(3.71)$ & PTF has very low to very high diversity weighted to the measure of species richness ${ }^{73}$. \\
\hline Brillouin index & $0.85-2.60(1.91)$ & Reflects the same information with $H^{\prime}$, though values are lower than $H^{\prime 47,49}$. \\
\hline Mackintosh diversity index & $0.74-2.55(1.75)$ & $\begin{array}{l}\text { Very low to moderate diversity; reflects similar trend with } H^{\prime} \text { and Brillouin indices, as } \\
\text { the index was weighted towards species dominance }{ }^{66} \text {. }\end{array}$ \\
\hline Menhinick diversity index & $0.42-1.56(0.91)$ & Very low diversity under condition of reduced effect of abundance to species richness. \\
\hline $\begin{array}{l}\text { Simpson's diversity (S 1-D) } \\
\text { index }\end{array}$ & $0.35-0.90(0.73)$ & $\begin{array}{l}\text { Low to moderate diversity (forest with uneven to even species composition). PTF is } \\
\text { dominated by few most abundant species attributed to relative abundance of each } \\
\text { species, as } 1 \text { represents infinite diversity and } 0 \text { represents no diversity }{ }^{67} \text {. }\end{array}$ \\
\hline $\begin{array}{l}\text { Berger-Parker dominance } \\
\text { index }\end{array}$ & $0.20-0.80(0.41)$ & $\begin{array}{l}\text { PTF has low to high species dominance. The species composition is uneven and values } \\
\text { are more weighted to the most abundant (dominant) species. An increase in the value } \\
\text { accompanies an increase in diversity and a reduction in dominance }{ }^{47,74,75} \text {. }\end{array}$ \\
\hline Pielou's evenness index $\left(e^{\mathrm{H} / \mathrm{S}}\right)$ & $0.10-0.54(0.32)$ & $\begin{array}{l}\text { Very low to mid-range of evenness as } E^{\prime} \text { ranges normally between } 0 \text { and } 1 \text {, where } 1 \text { rep- } \\
\text { resenting a situation in which abundance is equally (evenly) distributed among species } \\
\text { in the samples }{ }^{47,76} \text {. }\end{array}$ \\
\hline $\begin{array}{l}\text { Simpson's concentration of } \\
\text { dominance (D) }\end{array}$ & $0.09-0.65(0.27)$ & $\begin{array}{l}\text { Low diversity as individuals }(N) \text { are not equally (or evenly) distributed among species } \\
\text { resulting in low evenness (nearly } 0 \text { ), while some species dominated the forest (above } \\
\text { mid-value but far from approaching } 1 \text { ). Low evenness indicates high dominance in the } \\
\text { presence of a few species }{ }^{77} \text {. Similar tendency with } e^{\mathrm{H} / \mathrm{S}} \text { and Berger-Parker index. }\end{array}$ \\
\hline Shannon's equitability $(J)$ & $0.32-0.82(0.61)$ & $\begin{array}{l}\text { PTF has low to moderate species equity. It reflects similar information with Pielou's } \\
\text { evenness index. When all species are equally abundant, an evenness index would be at } \\
\text { a maximum (1.0) and decrease towards zero as the relative abundances of the species } \\
\text { diverge away from evenness }{ }^{72} \text {. }\end{array}$ \\
\hline Whittaker beta diversity $\left(\beta_{\mathrm{w}}\right)$ & $0.83-3.02(1.96)$ & $\begin{array}{l}\text { Low to moderate diversity; low }(<1) \text { to high }(\geq 5) \text { but does not have a fixed maximum } \\
\text { value. Increasing } \beta_{\mathrm{w}} \text { indicate that there are many species not shared among the } \\
\text { sample units }{ }^{50,78} \text {. }\end{array}$ \\
\hline
\end{tabular}

Table 2. Chao estimates for species richness in PTF

\begin{tabular}{lc}
\hline Characteristics/parameters & Value \\
\hline Number of pooled samples & 24 \\
Total species abundance, stem density $(N)$ & 25,435 \\
Total observed, recorded species $\left(S_{\text {obs }}\right)$ & 128 \\
Chao 1 $(F=13$ singletons and 2 doubletons) & 141 \\
Chao 2 $(F=42$ uniques and 18 duplicates) & 172 \\
Bootstrap & 145.82 \\
Degree or intensity of species collection $(\%)$ & $74.42-90.78$ \\
\hline
\end{tabular}

regardless of abundance ${ }^{47-49}$. The values obtained for Brillouin, Mackintosh and Menhinick indices showed similar tendency with $H^{\prime}$ (Table 1).
The other measures of diversity such as dominance (Simpson's 1D, Berger-Parker, Simpson's D), evenness (Pielou's $E$ ) and equity (Shannon's $J$ ) all reflect low to moderate diversity (Table 1), as their values diverge away from complete evenness (1) and decreasing towards zero (0). This shows that PTF is dominated by the most abundant species. The increasing values of Whittaker beta diversity $\left(\beta_{\mathrm{w}}\right)$, on the other hand, indicates that there are many species not shared in all the quadrats which can be attributed to rare, doubleton and singleton taxa. Both $\beta_{\mathrm{w}}$ and the above-mentioned alpha diversity indices together measure the overall diversity or biotic heterogeneity of an area ${ }^{50,51}$. 


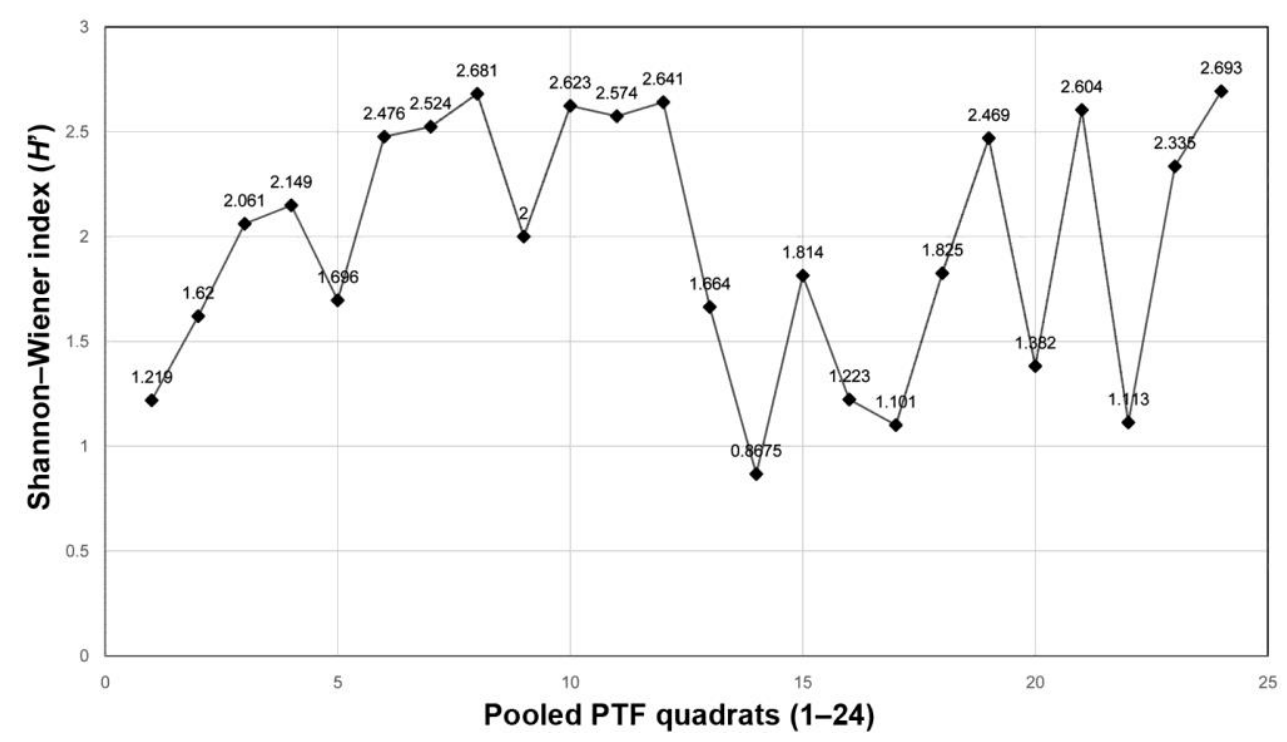

Figure 4. Shannon-Wiener diversity values of PTF across 24 quadrats.

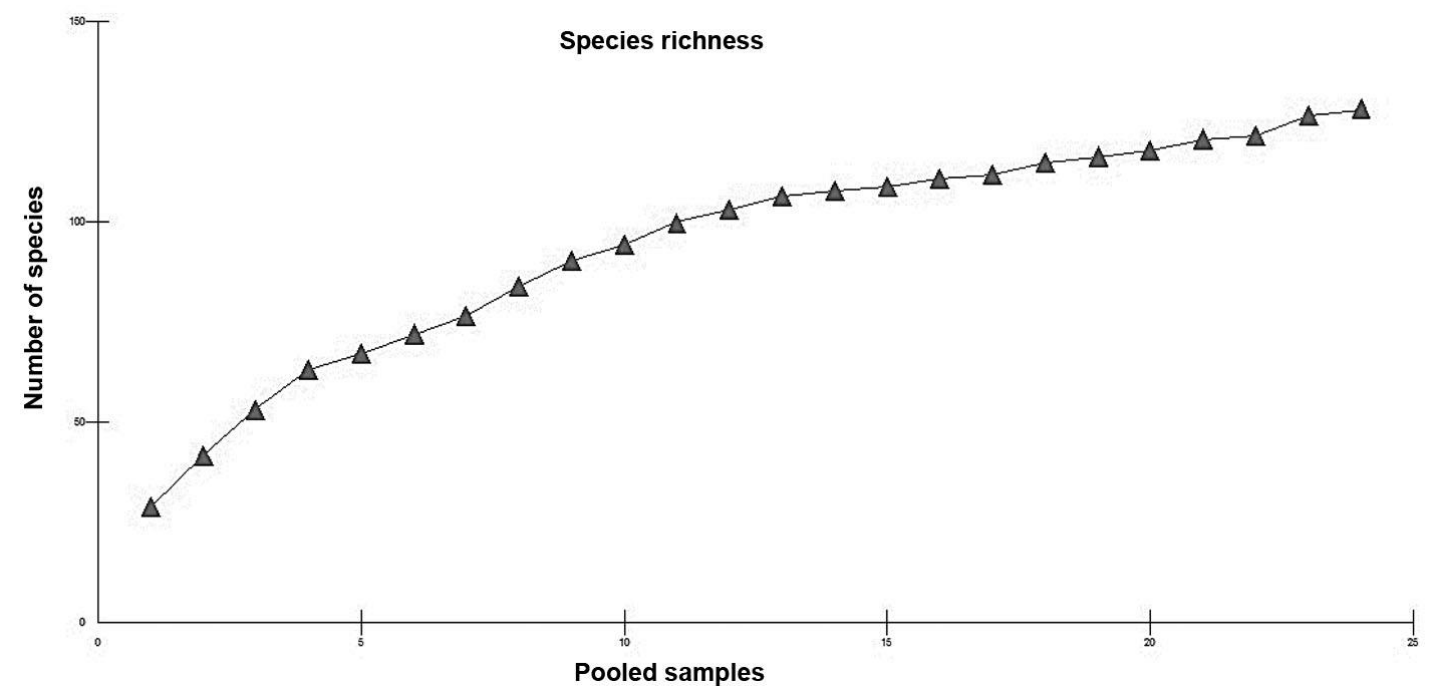

Figure 5. Species richness ( $y$-axis) accumulation curve pooled from 24 quadrats ( $x$-axis) in the PTF landscape using BioDiversityPro software of McALeece et al. ${ }^{40}$.

\section{Discussion}

Floristic composition, species diversity and interface with human agroscape

SR (= 128 species) in the present study is higher than the number of species reported from a previous study ${ }^{52}$ for PTF in Batangas, which accounted for 47 species over the range 11-30 species per plot. According to Heck et al. ${ }^{53}$, the recording of at least $50-75 \%$ of the total species of a given plant community is sufficient. Apart from trees, the present study has incorporated other possible morphospecies, including 'unseen' or rare species (e.g. palm-like Cycas, sedges, undershrubs, climbers, ferns, grasses, epi- phytes and geophytes). It was found that 80 species (63\%) were abundant, while $48(37 \%)$ were rare. Rare taxa (rare, doubleton and singleton) are those having low abundance or small ranges ${ }^{54}$, and a combination of biophysical factors could restrict either species abundance or geographical range ${ }^{55}$. The unexpected encounter with the rare Cycas suggests that the PTF landscape is of primitive origin. This remnant of Cycadales has flourished since the Cretaceous and Mesozoic era and is one of the most ancient coned plants found to this day in the IndoMalayan Archipelago ${ }^{56}$.

Fabaceae consisting of vines, shrubs and trees is the most species-rich plant group, indicating that PTF has interfaced with the agroecosystem landuse. This is evident 
with the occurrence of locally important cultivated trees such as Gliricidia sepium and Leucaena leucocephala as well as naturalized stands of Tamarindus indi$c a-a$ commercially valuable fruit tree in southern Batangas. Gliricidia and Leucaena are used as biofence, fodder and fuelwood, especially in managed hilly farms. The dominance of Fabaceae is an indication that the PTF is within the agro-forest landscape of Lobo Batangas Watershed ${ }^{52}$.

The species composition of PTF is a representation from ridge to coast having very low to moderate species diversity, some less disturbed while other sites are more altered by human presence. Disturbance-indicator genera are Annona, Chromolaena, Lantana, Leucaena, Mimosa, Gliricidia, Gmelina, Psidium and Saccharum. Since 1970s, commercial fruit-bearing Annona squamosa and introduced fodder-fuelwood Leucaena leucocephala have been components of the agroecosystem landscape in southern Batangas ${ }^{57,58}$, where the centre distribution of the Philippine teak population was first assessed ${ }^{17}$. Moreover, many weed trees and shrubs of an 'open area phenomenon' such as Acacia, Antidesma, Bauhinia, Gliricidia, Macaranga, Mallotus, Melanolepis, Mimosa and Tamarindus are found in the PTF landscape. These genera, if not outright disturbances, are bio-indicators of anthropogenic coexistence with the PTF. Elsewhere in tropical Asia, many of the aforementioned floristic elements are typical in savannah, abandoned farms, forest edges and disturbed woodlands ${ }^{59-61}$.

SR is a clear biological measure of alpha $(\alpha)$ diversity and is expressed simply as the number of recorded species in the sampled habitat ${ }^{50}$. Generally, the results imply that SR and abundance can be used as helpful diversity measures of regenerative potential of PTF. This forest superficially allows regeneration or turnover of many other species, as evident from the low to very high number of individuals. Hence, it can be considered as not anti-succession, which means that regeneration of future floristic composition can be sustained naturally.

Regardless of growth forms, dominance in the plant communities of the PTF landscape is expected among individual taxa with greater or high abundance $(N)$, resulting in low mean evenness $(0.32)$ to moderate equity (0.61). Human-propelled landscape alterations such as farming, deforestation for exotic plantation establishment and influx of settlement have all contributed to fragmentation of native tropical forests. They create gaps among fragments, isolating the native plant populations and spreading the alien species over the forest gaps and edges resulting in a deleterious, eliminating impact on native plant diversity ${ }^{62,63}$. This could be the reason for the low to moderate species heterogeneity $\left(H^{\prime}\right)$ in the PTF, resulting not only from the shares of native plant population where T. philippinensis was among the most abundant tree element, but by the contribution of abundant generalist, non-native ruderal flora with Asiatic or pantropic distributions.

\section{Conclusion}

The PTF is composed of a large number of non-woody and woody species. High SR, diverse morpho-species and very low to moderate level of heterogeneity characterize the PTF in the predominantly agro-ecosystem landscape. High abundance is shared by both endemic-indigenous and disturbance-indicator species, while low abundance has been recorded in rare, doubleton and singleton taxa collectively resulting in low evenness and equity. The proportion of trees is higher than other floristic growths.

The presence of PTF in a provincial scale suggests the narrow distribution of the Philippine teak resulting in endemicity. This is typical of many tropical forests which have been reduced to small, island-like regions called 'refugia' following significant climatic changes during the Pleistocene, which involved decreased precipitation and changes in sea level. These tropical forests often show particularly moderate to high levels of plant diversity and endemism ${ }^{64}$. Overall, the floristics of the PTF is comparable with other Philippine ecotypes as classified according to dominant flora, altitude and local geographic distribution. The PTF along the coastal landscape of Verde Island Passage needs to be added to the list of forest formations of the Philippines on account of its uniqueness with abundance of an endangered, endemic T. philippinensis.

1. Whitmore, T. C., Tropical Rain Forest of the Far East, Clarendon Press, Oxford, UK, 1975.

2. Whitmore, T. C., An Introduction to Tropical Rain Forests, Oxford University Press, Oxford, UK, 2nd edn, 1998.

3. Newbery, D. McC., Campbell, E. J. F., Lee, Y. F., Ridsdale, C. E. and Still, M. J., Primary lowland dipterocarp forest at Danum Valley, Sabah, Malaysia: structure, relative abundance and family composition. Philos. Trans. R. Soc., London, Ser. B, 1992, 335, 341-356.

4. Newbery, D. McC. Kennedy, D. N., Petol, G. H., Madani and Ridsdale, C. E., Primary forest dynamics in lowland dipterocarp forest at Danum Valley, Sabah, Malaysia and the role of understorey. Philos. Trans. R. Soc., London, Ser. B, 1999, 354, 1763-1782.

5. Buot Jr, I. E. and Okitsu, S., Vertical distribution and structure of the tree vegetation in the montane forest of Mt. Pulag, Cordillera mountain range, the highest mountain in Luzon Is., Philippines. Veg. Sci., 1998, 15, 19-32.

6. Belonias, B. S. and Aguilar, N. O., Altitudinal zonation of dicots on Mt. Pangasugan, Leyte Island, Philippines. J. Environ. Sci. Manage., 2004, 7(2), 47-66.

7. Buot Jr, I. E. and Osumi, K., Landuse type pattern and woody species composition near human disturbed landscapes on mount Makiling, Luzon Island. Am. J. Environ. Sci., 2011, 7(4), 306315.

8. Ferreras, U. F., Acopiado, M. S. D., Manglicmot, D. R. and Acedillo, R. M., A preliminary study on the floristic composition and structure of a lowland evergreen rainforest in Mt. Magdiwata, Agusan del Sur, Philippines. Sylvatrop, Tech., J. Philip. Ecosyst. Nat. Resour., 2011, 21(1\&2), 61-105. 
9. Heng, R. K. J. et al., Tree diversity at Payeh Maga Montane Forest, Sarawak, Borneo. J. Trop. Biol. Conserv., 2017, 14, 125-150.

10. Department of Environment and Natural Resources (DENR) United Nations Environment Program, Philippine Biodiversity: An Assessment and Action Plan, Bookmark. Inc., Manila, Philippine, 1997.

11. Pulhin, J. M. Trends in forest policy in the Philippines. In Policy Trend Report, Institute for Global Environmental Strategies, Japan, 2002, pp. 29-41.

12. Fernando, E. S., Suh, M. H., Lee, J. and Lee, D. K., Forest Formations of the Philippines, Seoul National University, Korea, 2008, p. 232.

13. Whitford, H. N., The forests of the Philippines. I. Philipp Bur. For. Bull., 1911, 19(1), 1-94.

14. Whitmore, T. C., Tropical Rain Forests of the Far East, Oxford University Press, Oxford, UK, 1984, 2nd edn.

15. Tan, B. and Rojo, J. P., Floristic inventory of the Philippine tropical rain forests. In Floristic Inventory of Tropical Countries (eds Campbell, D. G. and Hammond, D.), New York, USA, 1988, pp. $42-62$.

16. Madulid, D. A., Plant diversity in the Philippines. In Proceedings of the International Symposium on Biodiversity and Terrestrial Ecosystems (eds Peng, C. I. and Chou, C. H.), Institute of Botany, Academia Sinica Monograph Series, No. 14, Taipei, 1994, pp. 105-109.

17. Madulid, D. A. and Agoo, E. M. G., Conservation status of Tectona philippinensis Benth. \& Hook.f., a threatened plant. Acta Manila, 1990, 38, 41-56.

18. Cordon, A. B., Andres, A. L. B., Flores, M. R. L., Matias, M. S and Agoo, E. M. G., Vegetation analysis of the forest over limestome in two sites in Batangas, Philippines. Philipp. Sci., 2004, 41, 127-136.

19. Caringal, A. M. and Makahiya, A. M., Field study of Philippine teak (Tectona philippinensis Benth. \& Hook.f.) in Lobo, Batangas: rediscovering a century-old botanical treasure and global heritage. PBMIT Res. J., 2000, 4(2), 15-29.

20. Caringal, A. M., Buot Jr, I. E. and Aragones Jr, E. G., Population and reproductive phenology of the Philippine teak (Tectona philippinensis Benth. \& Hook.f.) in Lobo coast of Verde Island Passage, Batangas, Philippines. Philipp. Agric. Sci., 2015, 98(3), 312-322.

21. Hernandez, J. O., Malabrigo Jr, P. L., Quimado, M. O., Maldia, L. S. J. and Fernando, E. S., Xerophytic characteristics of Tectona philippinensis Benth. \& Hook.f. Philipp. J. Sci., 2016, 145(3), 259-269.

22. Agoo, E. M. G. and Oyong, G. G., Assessment of genetic diversity in Tectona philippinensis Benth. \& Hook.f. (Verbenaceae) inferred from TRNL intron sequences. Philipp. Sci., 2008, 45, 80-89.

23. Madulid, D. A., Agoo, M. G. E. and Caringal, A. M., Tectona philippinensis. The IUCN Red List of Threatened Species, 2008; www.iucnredlist.org.

24. DENR, National Biodiversity Strategy and Action Plan/Philippine Biodiversity: An Assessment and Action Plan, Bookmark, Inc. Makati, Philippines, 1997.

25. DENR Parks and Wildlife Bureau, The Verde Framework: The Verde Island Passage Marine Corridor Management Plan Framework. Quezon City, Philippines, 2009.

26. Regional Development Council (RDC), CALABARZON Regional Development Plan (2011-2016), Calamba City, Philippines, 2016.

27. Bureau of Soils, Land Resources Evaluation Project: Physical Land Resources, Province of Batangas Vol. 1, Bureau of Soils Publ., Manila, 1987.

28. Caringal, A. M., Biodiversity assessment in Lobo-San Juan Mountains, Mt. Forum Bull., 2007, 7(1), 7-8.

29. Cox, D. M., Mineral resources estimate upgrade on the Kay Tanda Project, Luzon, Philippines (NI 43-101 Report). Mindoro Resources Limited, Alberta, Canada, 2010.
30. Erenso, F., Maryo, M. and Abebe, W., Floristic composition, diversity and vegetation structure of woody plant communities in Boda dry evergreen Montane Forest, West Showa, Ethiopia. Int. J. Biodivers. Conserv., 2014, 6(5), 382-391.

31. Almazol, A. E. and Quintana, S. B., Tree species composition and physiognomy of Kinabuhayan River riparian zones, Mt. Banahaw-San Cristobal protected landscape. Sylvatrop, Tech. J. Philipp. Ecosyst. Nat. Resour., 2009, 19(1\&2), 29-56.

32. Rojo, J. P., Revised Lexicon of Philippine Trees, Department of Science and Technology-Forest Products Research and Development Institute, Los Baños, Laguna, Philippines, 1999.

33. Merrill, E. D., Enumeration of Philippine Flowering Plants Vols. 1-4, Bureau of Printing, Manila, 1923-1926.

34. Fernando, E. S., Sun, B. Y., Suh, M. H., Kong, H. Y. and Koh, K. H., Flowering Plants and Ferns of Mt. Makiling, Seoul National University, Korea, 2004.

35. Madulid, D. A., A Dictionary of Philippine Plant Names, Vol. 1, The Bookmark, Inc., Makati City, Philippines, 2001.

36. International Plant Names Index, 2019; http://ipni.org

37. Smith, A. R., Kathleen, M. P., Schuettpelz, E., Korall, P. Schneider, H. and Wolf, P. G., A classification of extant ferns. Taxon, 2006, 55(3), 705-731.

38. Pteridophyte Phylogeny Group I, A community derived classification for extant lycophytes and ferns. J. Syst. Evol., 2016, 54(6), $563-603$.

39. The Angiosperm Phylogeny Group, An update of the Angiosperm Phylogeny Group classification for the orders and families of flowering plants: APG IV. Bot. J. Linn. Soc., 2016, 181, 1-20.

40. McAleece, N., Gage, J. D. G., Lambshead, P. J. D. and Paterson, G. L. J., BioDiversity Professional Statistics Analysis Software, Scottish Association for Marine Science and the Natural History Museum London, UK, 1997.

41. Hammer, O., Harper, D. A. T. and Ryan, P. D., Paleontological statistics (PAST) package for education and data analysis software v2.10, 2010

42. Langenberger, G., A review of research on Philippine forest vegetation, particularly work since 1990. Agham Mindanaw., 2004, 2, 11-24.

43. Colwell, R. K., EstimateS: statistical estimation of species richness and shared species from samples, version 8.2, 2009.

44. Dansereau, P., Biogeography, An Ecological Perspective, The Ronald Press, New York, USA, 1957.

45. Kershaw, K. A., Quantitative and Dynamic Ecology, Edward Arnold Publishing Co Ltd, London, UK, 1964.

46. Mueller-Dombois, D. and Ellenberg, H., Aims and Methods of Vegetation Ecology, Wiley, New York, USA, 2002.

47. Magurran, A. E., Ecological Diversity and its Measurement, Chapman and Hall, London, UK, 1988.

48. Hayek, L. C. and Buzas, M. A., Surveying Natural Populations, Columbia University Press, New York, 1997.

49. Williams, V. L., Witkwski, E. T. F. and Ballkill, K., Application of diversity indices to appraise plant availability in the traditional medicinal markets of Johannesburg, South Africa. Biodivers. Conserv., 2005, 14, 2971-3001.

50. Whittaker, R. H., Evolution and measurement of species diversity. Taxon, 1972, 21, 213-251.

51. Wilson, M. V. and Shmida, A., Measuring beta diversity with presence-absence data. J. Ecol., 1982, 72(3), 1055-1064.

52. Palis, H. G., Castillo, J. A. A. and Rivera, M. N., Plant diversity profile of the Lobo Watershed in Lobo, Batangas. Sylvatrop, Tech. J. Philipp. Ecosyst. Nat. Resour., 2011, 21(1\&2), 370-383.

53. Heck, K. L., Van Belle, G. and Simberloff, D., Explicit calculation of the rarefaction diversity measurement and the determination of sufficient sample size. Ecology, 1975, 56, 1559-1461.

54. Gaston, K. J., What is rarity? In Rarity: Population and Community Biology Series, Vol. 13, Springer, Dordrecht, The Netherlands, 1994. 
55. Cowling, R. M., Diversity components in a species-rich area of the Cape Floristic region. J. Veg. Sci., 1990, 1, 699-710.

56. Lindstrom, A. J. and Stanberg, L. C., The genus Cycas (Cycadaceae) in the Philippines. Telopea, 2008, 12(1), 119-145.

57. Bueno, P. B., Dissemination and utilization of information on giant ipil-ipil (Leucaena leucocephala Lam. De Witt) in the Batangas Greening Movement. Sylvatrop Philipp. For. Res. J., 1978, 3(2), 65-84.

58. Cueto, L. A. and Caringal, A. M., Management of indigenous mountain rice and fodder tree: short notes on the lowest practice climate change mitigation. Mt. Forum Bull., 2008, VIII(1), 15.

59. Gentle, C. B. and Duggin, J. A., Lantana camara L. invasions in dry rainforest-open forest ecotones: the role of disturbances associated with fire and cattle grazing. Aust. J. Ecol., 1997, 22, 298-306.

60. Guingab, M. V. D., Promising woody species for grassland rehabilitation in northeastern Luzon, Philippines. Grassl. Soc. Philipp. J., 1998, 2(2), 1-10.

61. Weerd, M. V., Strijk, J. and Snelder, D., The importance of forest fragments for birds and local communities in Northeastern Luzon, Philippines. Sylvatrop, Tech. J. Philipp. Ecosyst. Nat. Resour., 2003, 13(1\&2), 1-30.

62. Dar, P. A., Reshi, Z. A. and Shah, M. A., Roads act as corridors for the spread of alien plant species in the mountainous regions: a case study of Kashmir Valley, India. Trop. Ecol., 2015, 56(2), 183-190.

63. Joshi, A. A., Mudappa, D. and Shankan Raman, T. R., Invasive alien species in relation to edges and forest structure in tropical rainforest fragments of the Western Ghats. Trop. Ecol., 2015, 56(2), 233-244.

64. Singh, S. P., Chronic disturbance, a principal cause of environmental degradation in developing countries. Environ. Conserv., 1998, 25, 1-2.

65. Shannon, C. E., A mathematical theory of communication. In Mathematical Theory of Communication (eds Shannon, C. E. and Weaver, W.), University of Illinois Press, Urbana, Illinois, 1949, pp. 29-125.

66. McIntosh, R. P., An index of diversity in relation to certain concepts to diversity. Ecology, 1967, 48, 392-402.

67. Hurlbert, S. H., The nonconcept of species diversity: a critique and alternative parameters. Ecology, 1971, 52, 577-586.

68. Bunge, J. and Fitzpatrick, M., Estimating the number of species: a review. J. Am. Stat. Assoc., 1993, 88(421), 354-373.
69. Colwell, R. K. and Coddington, A. J., Estimating terrestrial biodiversity through extrapolation. Philos. Trans. R. Soc. London, Ser. $B, 1994, \mathbf{3 4 5}, 101-118$.

70. Mao, C. X. and Colwell, R. K., Estimation of species richness: mixture models, the role of rare species, and inferential challenges. Ecology, 2005, 86(5), 1143-1153.

71. Hill, M. O., Diversity and evenness: a unifying notation and its consequences. Ecology, 1973, 54(2), 427-432.

72. Ludwig, J. A. and Reynolds, J. F., Statistical Ecology - A Primer on Methods and Computing, John Wiley, Toronto, Canada, 1988.

73. Margalef, D. R., Information theory in ecology. Gen. Syst., 1958, 3, 36-71.

74. May, R. M., Patterns of species abundance and diversity. In Ecology and Evolution of Communities (eds Cody, M. L. and Diamond, J. M.), Harvard University Press, Cambridge, MA, USA, 1975, pp. 81-120.

75. Yeom, D. J. and Kim, J. H., Comparative evaluation of species diversity indices in the natural deciduous forest of Jeombong. J. For. Sci. Technol., 2011, 7(2), 68-74.

76. Pielou, E. C., Species diversity and pattern diversity in the study of ecological succession. J. Theor. Biol., 1966, 10, 370-383.

77. Begossi, A., Use of ecological methods in ethnobotany: diversity indices. Econ. Bot., 1996, 50, 280-289.

78. McCune, B., Grace, J. B. and Urban, D. L., Analysis of Ecological Communities, Vol. 28, Gleneden Beach, OR, MjM software design, 2002.

ACKNOWLEDGEMENTS. This study was made possible with funding support from the Department of Science and Technology-Accelerated Science and Technology Human Resource Development Programme (DOST-ASTHRDP) through the Graduate School and School of Environmental Science and Management, University of the Philippines Los Baňos, Phillippines (GS/SESAM, UPLB). The botanical herbarium collections in Lobo, Batangas was also partially funded by the Batangas State University under its research fund.

Received 18 November 2019; accepted 11 December 2020

doi: $10.18520 / \mathrm{cs} / \mathrm{v} 120 / \mathrm{i} 6 / 1057-1065$ 